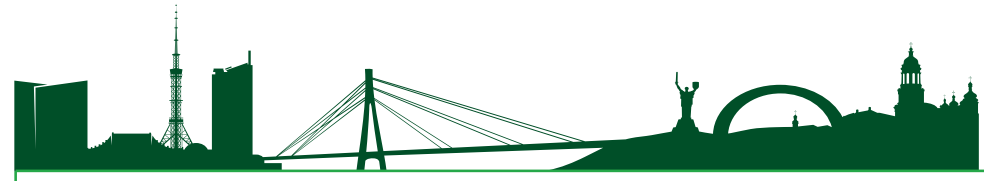

UDC 624.04:41

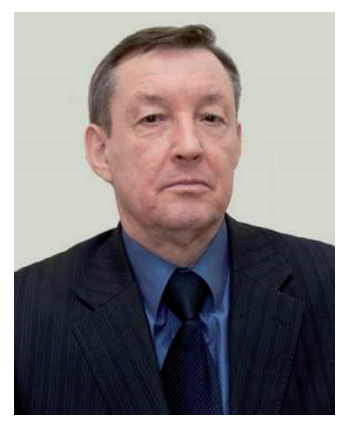

SHKURUPIY A.A.

PhD, Prof., professor, head of the department, Poltava National Technical Yuri Kondratyuk University, Poltava, Ukraine, e-mail: shbm@ukr.net, tel. +38 (066) 836-89-41, ORCID: 0000-0003-1487-1037

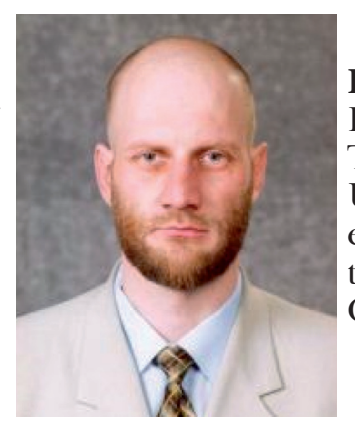

PASCHENKO A.N.

PhD, ass. prof., Poltava National Technical Yuri Kondratyuk University, Poltava, Ukraine, e-mail: Pan_docent@ukr.net, tel. +38 (095) 728-81-55, ORCID: 0000-0002-6562-0046

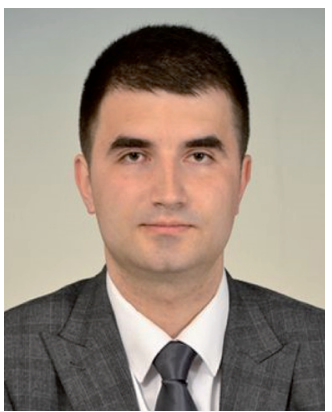

MYTROFANOV P.B.

PhD, ass. prof., Poltava National Technical Yuri Kondratyuk University, Poltava, Ukraine, e-mail: Mytrofanov.P@gmail.com, tel. +38 (050) 849-22-88, ORCID: 0000-0003-4274-1336

\title{
ALGORITHM AND SOFTWARE FOR CALCULATING THE STABILITY OF THE FORM OF EQUILIBRIUM OF DISCRETE SYSTEMS
}

ABSTRACT. The paper presents an algorithm for calculating the stability of the form of equilibrium of the first kind of compressed discrete systems by the method of displacements in combination with the methods of iterations and bisection. The use of the displacement method in combination with the iteration and bisection methods makes it possible to effectively determine the minimum critical stress or strain at the first bifurcation and their corresponding form of loss of stability, both for statically determined and statically undetectable systems. This approach, using matrix forms, makes it possible to significantly simplify the calculations of the analytical condition for the loss of stability of compressed discrete systems (the stability loss equation), which has high orders, as well as to construct the form of loss of stability corresponding to a critical load, that is, to solve the problem of loss of stability of equilibrium. The calculation of the compressed discrete system on the stability of the form of equilibrium actually reduces to the solution of the difficultly described nonlinear transcendental equation, which is the equation of loss of stability. The difficulty lies in the absence of an analytical solution of such an equation due to the presence of complex functions of Zhukovsky, which have transcendental functions in their structure. Such solution can be performed only with the use of numerical methods. This algorithm for calculating the loss of equilibrium of the first kind of compressed discrete systems by displacement in combination with the methods of iteration and bisection is implemented in the software complex "Persist" for a PC in Windows OS. The program was approbated and implemented in the educational process at the Department of Structural and Theoretical Mechanics of the Poltava National Technical Yuri Kondratyuk University during the training of specialists in engineering specialties.

KEYWORDS: stability, critical state, critical load, critical stress, loss of stability of the form of equilibrium (deformation), bifurcation, form of loss of stability, iteration, bisection.

\section{ШКУРУПІЙ О.А.}

Канд. технічних наук, проф., Полтавський національний технічний університет ім. Юрія Кондратюка, Полтава, Україна,

e-mail:shbm@ukr.net,

тел. +38 (066) 836-89-41,

ORCID: 0000-0003-1487-1037

\section{ПАЩЕНКО А.М.}

Канд. технічних наук, доцент, Полтавський національний технічний університет ім. Юрія Кондратюка, Полтава, Україна,

e-mail: Pan_docent@ukr.net,

тел. +38 (095) 728-81-55,

ORCID: 0000-0002-6562-0046 


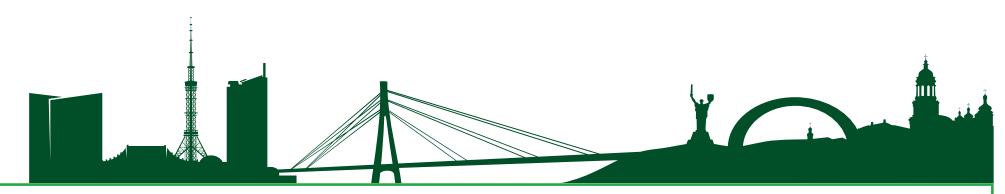

\section{МИТРОФАНОВ П.Б.}

Канд. технічних наук, доцент, Полтавський національний технічний університет ім. Юрія Кондратюка, Полтава, Україна, e-mail: Mytrofanov.P@gmail.com, tel. +38 (050) 849-22-88,

ORCID: 0000-0003-4274-1336

\section{АЛГОРИТМ I ПРОГРАМНИЙ КОМПАЕКС ДАЯ РОЗРАХУНКУ СТІЙКОСТІ ФОРМИ РІВНОВАГИ ДИСКРЕТНИХ СИСТЕМ}

АНОТАЦІЯ. У статті наведено алгоритм розрахунку стійкості форми рівноваги першого роду стиснутих дискретних систем методом переміщень у сукупності з методами інерцій та бісекції. Використання методу переміщень у сукупності 3 методами ітерацій та бісекції дає можливість ефективно визначати мінімальне критичне навантаження чи напруження при першій біфуркації та відповідну їм форму втрати стійкості, як для систем, що статично визначаються, так і для систем, що статично не визначаються. Такий підхід з використанням матричних форм дає можливість суттево спростити розрахунки аналітичної умови втрати стійкості стиснутих дискретних систем (рівняння втрати стійкості), котра має високі порядки, а також побудувати відповідну критичному навантаженню форму втрати стійкості, тобто вирішити задачу втрати стійкості рівноваги. Розрахунок стиснутої дискретної системи на стійкість форми рівноваги фактично зводиться до розв'язування складно описаного нелінійного трансцендентного рівняння, яким є рівняння втрати стійкості. Складність полягає у відсутності аналітичного розв'язання такого рівняння через наявність складних функцій Жуковського, які мають у своєму складі трансцендентні функції. Такий розв'язок можна виконати лише з застосуванням чисельних методів. Даний алгоритм розрахунку втрати стійкості рівноваги першого роду стиснутих дискретних систем методом переміщень в сукупності з методами інерцій та бісекції реалізований у програмному комплексі «Persist» для ПЕОМ в OS Windows. Програма пройшла апробацію та впроваджена в навчальний процес на кафедрі будівельної та теоретичної механіки Полтавського національного технічного університету імені Юрія Кондратюка при підготовці фахівців інженерних спеціальностей.

КЛЮЧОВІ СЛОВА: стійкість, критичний стан, критичне навантаження, критичне напруження, втрата стійкості форми рівноваги (деформації), біфуркація, форма втрати стійкості, ітерація, бісекція.

\section{INTRODUCTION}

There are various methods for calculating the stability of the shape of the equilibrium of discrete systems, due to the large volume of computations associated with the solution of the analytical condition for the loss of equilibrium stability. The solution of the analytical condition for the loss of stability of the equilibrium of compressed discrete systems, which has high orders, and the definition of the critical load of the form of loss of stability, is one of the topical problems.

\section{REVIEW OF RECENT SOURCES OF RESEARCH AND PUBLICATIONS}

The solution of the problem of calculating the analytical condition for loss of stability of the equilibrium of compressed discrete systems, which has high orders, and the determination of the corresponding critical load of the form of loss of stability, generated a large number of methods by many mathematicians (Krylov, Laverier, Danilevsky, Jacobi (iterations) $[1-10]$ etc.).

\section{PARTS OF THE COMMON PROBLEMS THAT EARLIER UNSOLVED}

The calculation of the compressed discrete system on the stability of the form of equilibrium actually reduces to the solution of the difficultly described nonlinear transcendental equation, which is the equation of loss of stability. The difficulty lies in the absence of analytical solution of such equation due to the presence of complex functions of Zhukovsky, which have transcendental functions in their structure. Such solution can be performed only with the use of numerical methods. This problem of calculating the analytical condition for loss of stability of the equilibrium of compressed discrete systems, as well as the determination of the critical load of the form of loss of stability, is proposed to solve by displacement, iteration and bisection methods, which makes it possible to significantly simplify calculations.

\section{PURPOSE OF THE WORK}

The purpose of the work is to develop an algorithm and software for the PC in Windows OS, which will enable students and engineers to automate calculations of stability of equilibrium forms of compressed discrete systems.

\section{MAIN MATERIAL AND RESULTS}

The algorithm for Calculation of the loss of stability of the form of equilibrium of the first kind of compressed discrete systems by the displacement method in combination with the methods of iterations and bisection with examples is given in [11]. It is implemented in the software package "Persist" for a $\mathrm{PC}$ in Windows OS.

In the Department of Structural and Theoretical Mechanics the «Persist» program was developed and 


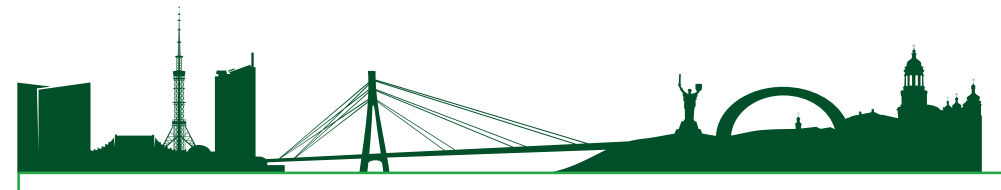

implemented on the PC. To solve this engineering task this computer program is implemented in a modern compiler, contains several subroutines that are combined and presented in the form of the same software complex.

General algorithm for calculating stability by the program "Persist".

Generalized structural scheme of solving equation of loss of stability:

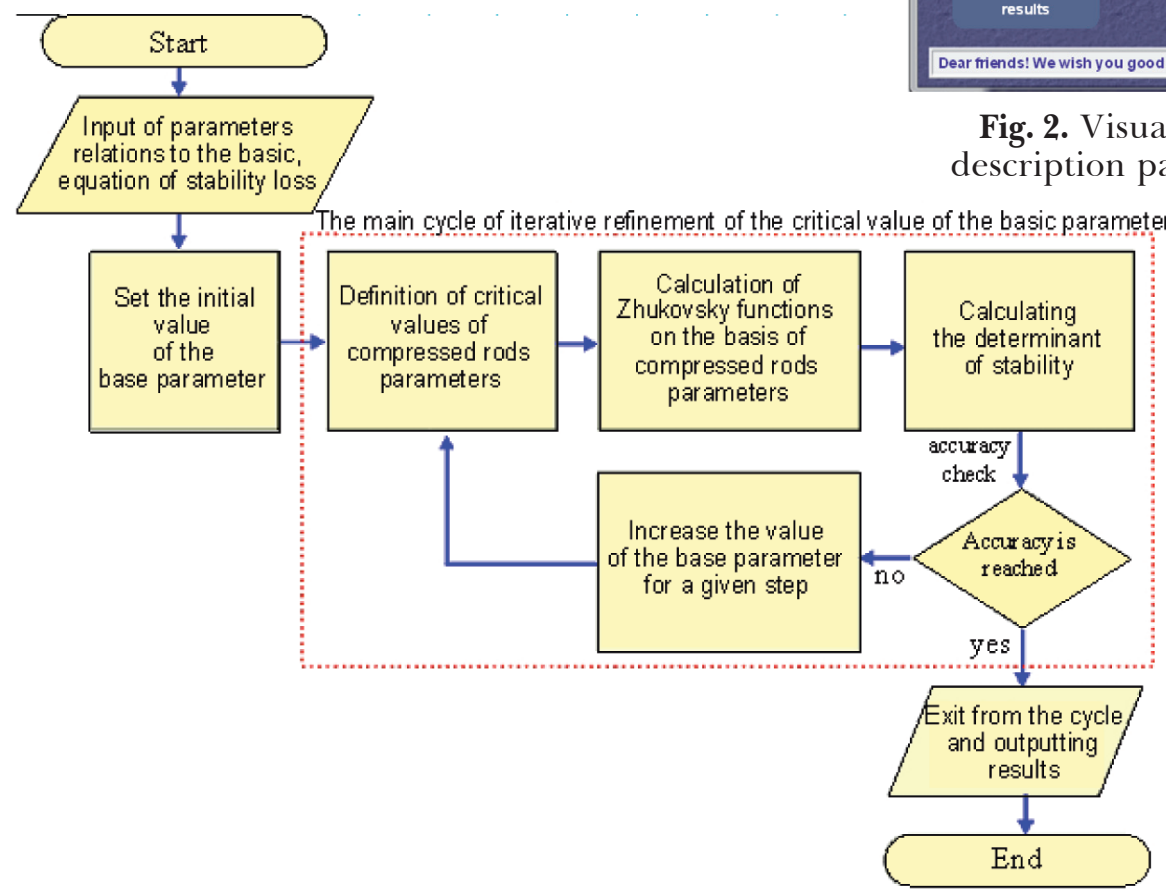

Fig. 1. Structural diagram of the algorithm for solving the equation of loss of stability

The calculation of the compressed frame on the stability of the form of equilibrium implies forming a loss-stability equation by yourself. Only after completing and checking the equation of loss of stability as a nontrivial solution of a homogeneous system of canonical equations, a user uses a PC to solve stability of the equilibrium form according to the "Persist" program.

The calculation of the compressed discrete system on the stability of the form of equilibrium actually reduces to the solution of the difficultly described nonlinear transcendental equation, which is the equation of loss of stability. The difficulty lies in the absence of an analytical solution of such equation due to the presence of complex functions of Zhukovsky, which have transcendental functions in their structure. The arguments of the functions of Zhukovsky are the values of the parameters of the compressed rods parameter t.

The main points of describing the source data in the program «Persist».

\section{Description of the compressed rods parameters.}

The dialog for describing the parameters of the compressed rods is activated by pressing the

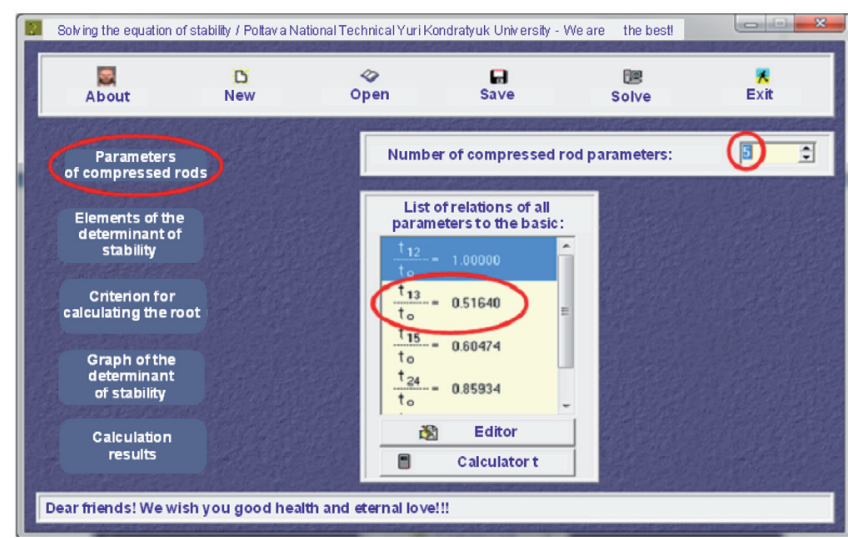

Fig. 2. Visual components for managing the description parameters of the compressed rods

corresponding button, Fig. 2. In this case, it should be noted that only non-zero parameters are described, that is, the parameters of only compressed rods, rods with zero value of longitudinal force are not part of the ones described.

\section{Introduction of elements of} equation of loss of stability of the form of equilibrium.

Determination of the first real root of the equation of equilibrium of loss of stability.

\section{Criteria setting for iterative calculation.}

As a precision criterion, the "Persist" program uses the socalled absolute criterion when the process of iterative refinement of the root stops when the absolute value of the desired root does not exceed the value of the given error, which is recommended to set in the range $10^{-6} \ldots 10^{-4}$. Fig. 6 shows an activated menu item for adjusting the criteria for an iterative calculation.

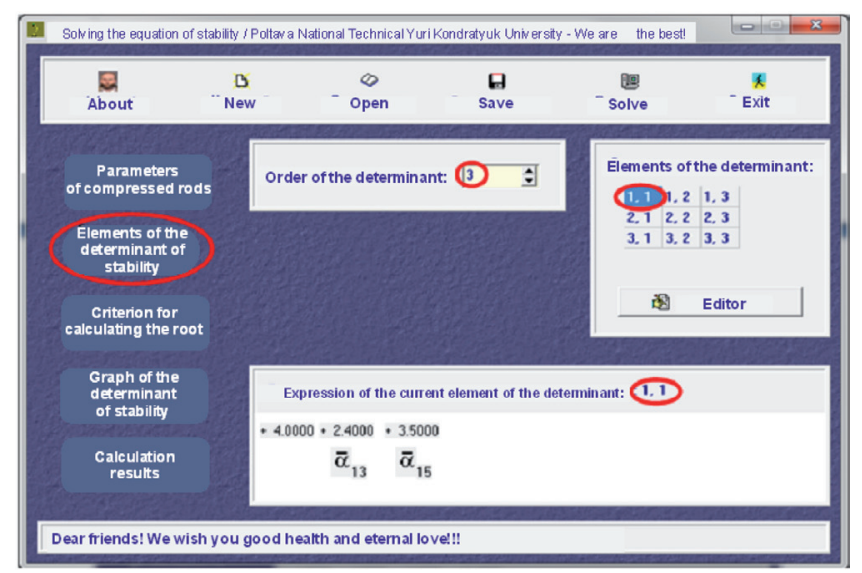

Fig. 3. Visual components of control description of stability loss elements equation of the equilibrium form 


\section{WHA 1 Man}

4. Directly solving equation of stability in «Persist».

As noted above, solving the equation of loss of stability of the form of equilibrium involves the use of numerical methods. Thus, in the "Persist" is organized an iterative process of solving a complex nonlinear

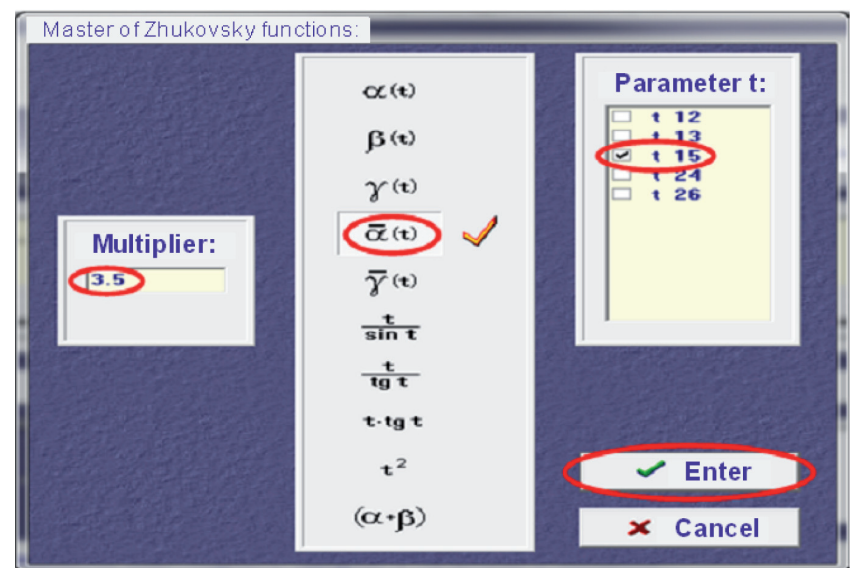

Fig. 4. Visual components of description control element 1.1 of stability equation loss of the equilibrium form

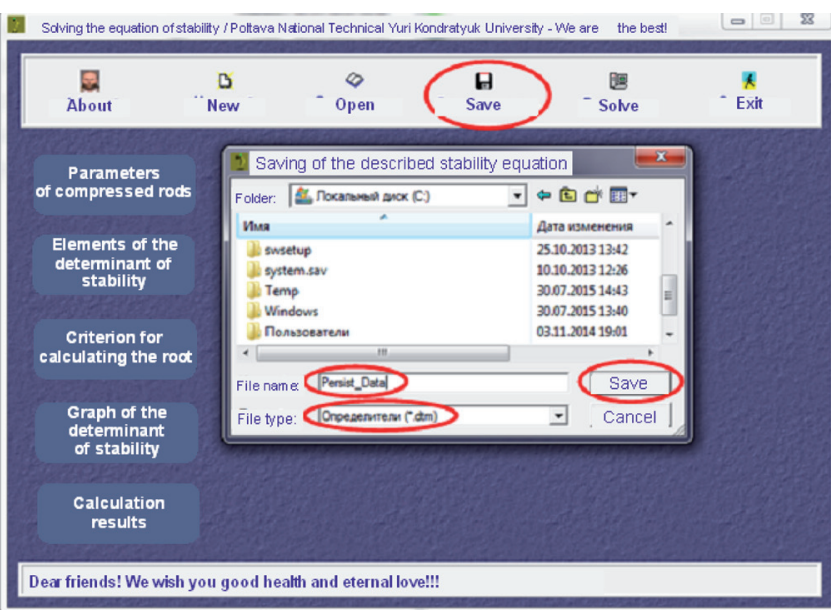

Fig. 5. Saving of the described stability equation loss of the equilibrium form

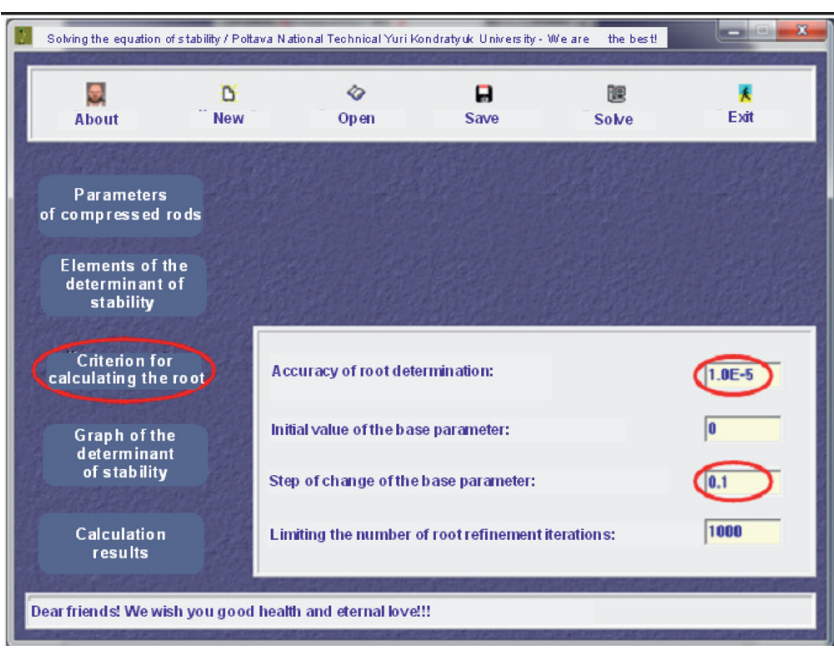

Fig. 6. Settings of criteria for iterative calculation equation using the chord method in conjunction with refinement on its iterations by the method of bisection. The search for the interval of existence of the first root is carried out by the method of selection as for the method of dichotomy. The process of iterative refinement of the root continues until the root value reaches the given accuracy.

For a solution already described in the program "Persist" equation of loss of stability of the form of equilibrium, the user must use the item in the main menu "Calculate", Fig. 2.

\section{Analysis and verification of calculation results.}

As you know, transcendental equations can have not one root due to the presence of periodic functions. According to the physical content of the equation of loss of stability, we are interested in the first root, which corresponds to the minimum critical value of the basic parameter of the compressed rod . On its basis, the critical values of the parameters of all compressed rods are determined as: , where ki coefficient of reduction of compressed rods lengths.

It is necessary to emphasize the prevention of the passage of the first root when numerically iterative solving of such equation. To do this, you need to analyze the results. As a rule, it is enough to visually assess the type of graph of the dependence of the determinant of stability of the form of equilibrium from the value of the basic parameter t0cr (Fig. 7).

Fig. 8 and Fig. 9 shows the results of the solution

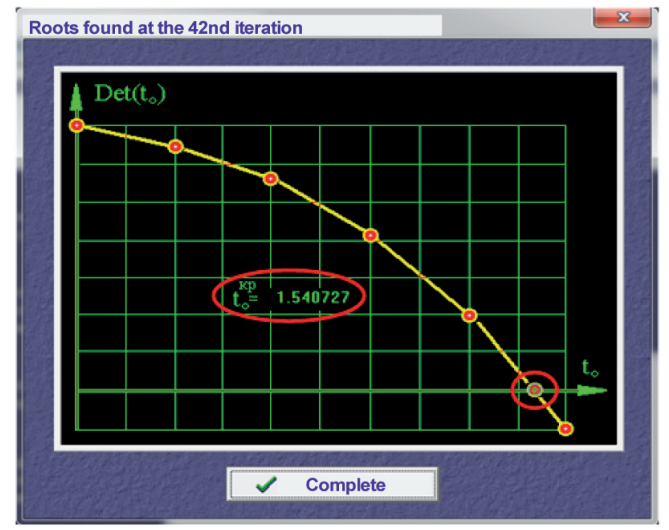

Fig. 7. Chart of the dependence of the determinant of resistance on the value of the basic parameter

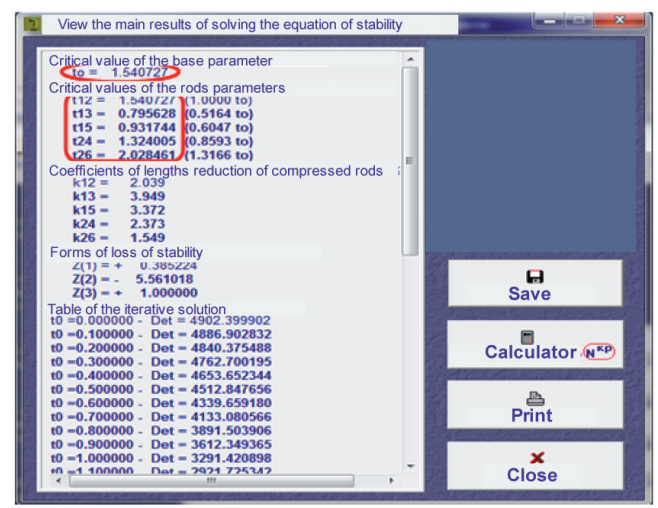

Fig. 8. View the results of the solution the equation of stability loss of the form of equilibrium 


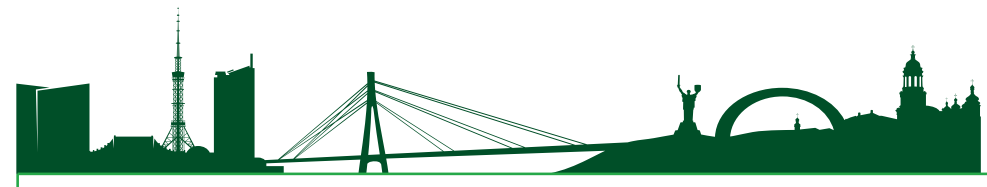

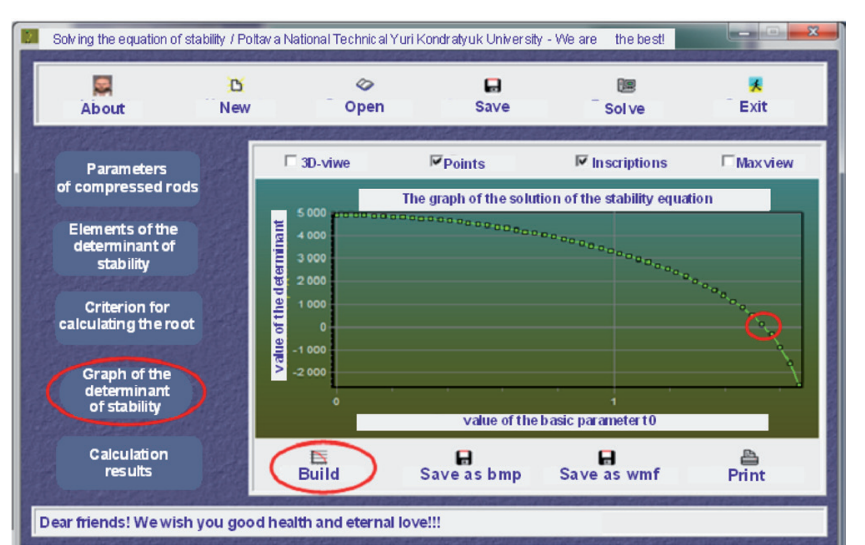

Fig. 9. Graphic representation of the solution of the stability loss equation

the equation of stability loss of the form of equilibrium in table and graph forms.

The user is able to adjust the accuracy of the graphical display of the solution of the equation of stability loss (Fig. 10). A calculator is available for the user which allows calculate the values of critical longitudinal forces (Fig. 11).

\section{Saving the results and getting a copy of them.}

For the possibility of further analysis and processing of the results of calculations in the "Persist" is provided the possibility of saving them in a text file. To do this,

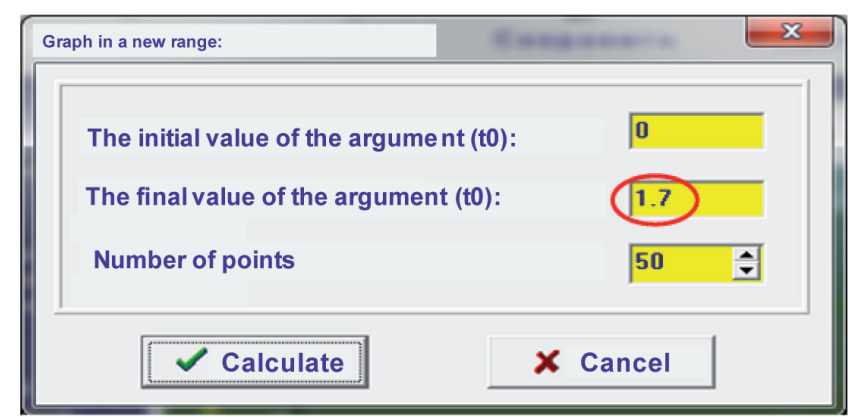

Fig. 10. Settings of the graphical representation of the equation of loss solution of stability of the equilibrium form

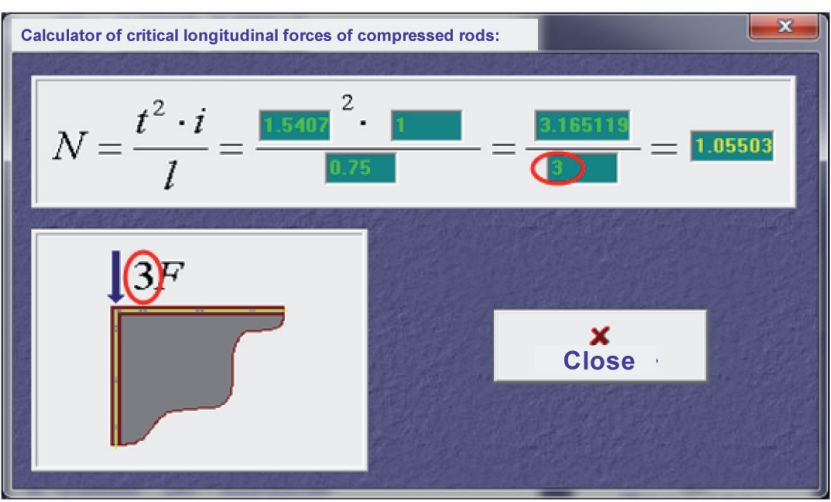

Fig. 11. Calculator for calculating critical longitudinal forces use the appropriate menu item "Save" in the viewport of the main results, see Fig. 2. In this case, all actions of saving file are absolutely similar to those used in any Windows program (Fig. 12).

A text file with results can be downloaded to any text editor to prepare for printing in a more userfriendly format.

\section{Main properties of "Persist" software}

Requirements for PC system resources. The program uses the Windows operating system. For ease of use, we recommend using monitors with a resolution of $800 \times 600$ pixels.

Software package Persist consist of files:

- Persist.exe (mandatory) - main program file;

- Persist.hlp (recommended) -help file for using "Persist";

- Persist.ini (optional) - initializing the values of the search criterion for the root equation of stability, can be created automatically;

- Persist.txt (optional) - file with a short description of the program;

- Demo*.dtm (optional) - demo files of the described equations of stability, which can be downloaded for calculation and analysis.

Copyrights. The program can be freely distributed, and authors are not liable for any losses incurred as a result of using this program (data loss, financial loss, etc.).

Due to the constant improvement of the program, authors recommend that you follow the release number in the About menu.

Installing software package «Persist» on PC. For correct operation of the program "Persist" you should install it on the hard disk of the PC. It is not desirable to launch the program directly from the CD. This is due to the need in certain cases saving data on hard disk. To install the "Persist" program on a PC, you need to copy the "Persist" subdirectory to the PC hard disk.

Conclusions. The algorithm and program complex "Persist" for the PC in Windows OS are developed. This computer program is implemented in a modern

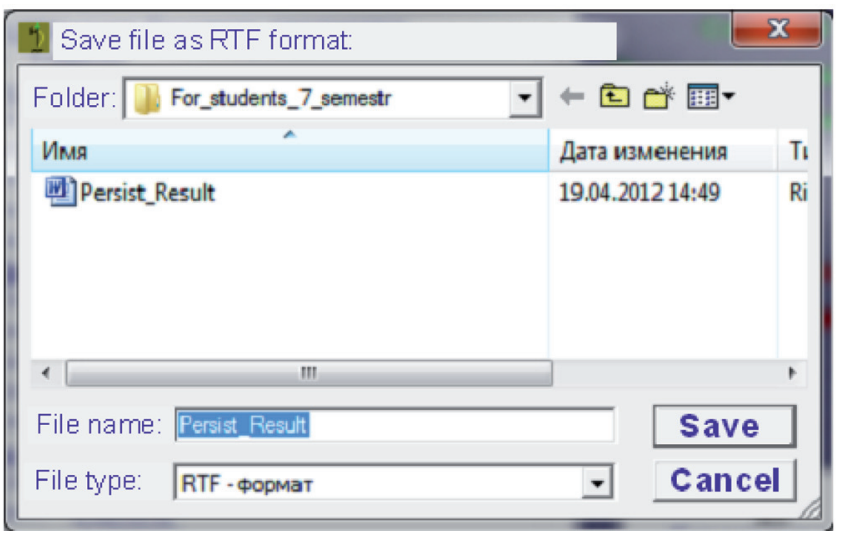

Fig. 12. Saving the results of solving the equation of stability loss in a text file 


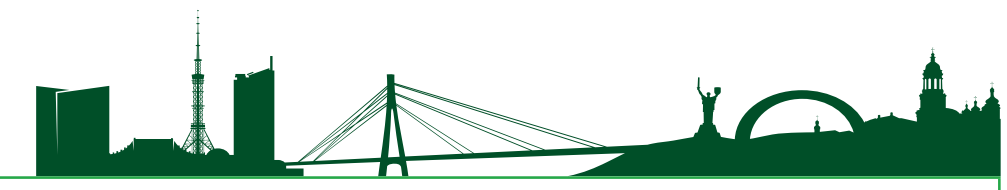

compiler, contains several subroutines (utilities), which are combined and presented in the form of the same software complex. It will enable students and engineers to automate calculations of the stability of the equilibrium form of compressed discrete systems, calculate critical loads (stresses) and determining the corresponding principal forms of oscillations. The program has been approbated and implemented in the educational process at the Poltava National Technical Yuri Kondratyuk University during the training of specialists in engineering specialties.

\section{БІБЛІОГРАФІЧНИЙ СПИСОК}

1. Строительная механика. Динамика и устойчивость сооружений / [А.Ф. Смирнов, А.В. Александров, Б.Я. Аащеников, Н.Н. Шапошников]. - М.: Стройиздат, 1984. - 415 с.

2. Киселев В.А. Строительная механика. Специальный курс. - 3-е изд., исправ. и доп. / В.А. Киселев. - М.: Стройиздат, 1980. - 616 с.

3. Баженов В.A. Будівельна механіка. Комп'ютерні технології: підручник / В.А. Баженов, А.В. Перельмутер, О.В. Шишов. - Київ: Каравела, 2009. - 696 с.

4. Баженов В.А. Будівельна механіка. Динаміка споруд: навч. посібник / В.А. Баженов, E.С. Дехтярюк. - Київ: ІЗМН, 1998. - 208 с.

5. Вибрации в технике: Справочник. В 6-ти томах / Ред. совет: В.Н. Челомей (предс.). Том 1. Колебания линейных систем. - Под ред. В.В. Болотина. - М.: Машиностроение, 1978. - 352 c.

6. Nageim H. Al. , Durka F., Morgan W. \& Williams D. Structural Mechanics . - Trans-Atlantic Publications, 2010. - 456 p.

7. Karl-Gunnar Olsson \& Ola Dahlblom. Structural Mechanics: Modelling and Analysis of Frames and Trusses. - Wiley, 2016. - 344 p.

8. Smith P.An Introduction to Structural Mechanics. - Palgrave Macmillan, 2001. - 368 p.

9. Ray Hulse \& Jack Cain Structural Mechanics. Palgrave Macmillan. 2000. - 592 p.

10. Фаддеев Д.К. Вычислительные методы линейной алгебры / Д.К. Фаддеев, В.Н. Фаддеева. - М.: Физматгиз, 1960. - 656 с.

11. Шкурупій О.А. Стійкість форми рівноваги та динаміка дискретних систем: навчальний посібник / О.А. Шкурупій. - Полтава: ПолтНТУ, 2015. -228 c.

\section{REFERENCES}

1. Smyrnov A.F. Stroytel'naya mekhanyka. Dynamyka y ustoychyvost' sooruzhenyy / A.F. Smyrnov, A.V. Aleksandrov, B.Ya. Lashchenykov, N.N. Shaposhnykov. M.: Stroyyzdat, 1984. -415 s.
2. Kyselev V.A. Stroytel'naya mekhanyka. Spetsyal'nuy kurs. - 3-e yzd., ysprav. y dop. / V.A. Kyselev. - M.: Stroyyzdat, 1980. - 616 s.

3. Bazhenov V.A. Budivel'na mekhanika. Komp"yuterni tekhnolohiyi: pidruchnyk / V.A. Bazhenov, A.V. Perel'muter, O.V. Shyshov. - K.: Karavela, 2009. - 696 s.

4. Bazhenov V.A. Budivel'na mekhanika. Dynamika sporud: navch. posibnyk / V.A. Bazhenov, Ye.S. Dekhtyaryuk. - Kyiv: IZMN, 1998. - 208 s.

5. Vybratsyy v tekhnyke: Spravochnyk. V 6-ty tomakh / Red.sovet: V.N. Chelomey (preds.). - Tom 1. Kolebanyya lyneynykh system. - Pod red. V.V. Bolotyna. - M.: Mashynostroenye, 1978. - 352 s.

6. Structural Mechanics / H. Al. Nageim, F. Durka, W. Morgan, D. Williams. - TransAtlantic Publications, 2010. - 456 p.

7. Olsson K.-G. Structural Mechanics: Modelling and Analysis of Frames and Trusses / KarlGunnar Olsson, Ola Dahlblom. - Wiley, 2016. - 344 p.

8. Smith P. An Introduction to Structural Mechanics / P. Smith. - Palgrave Macmillan, 2001. - 368 p.

9. Hulse R. Structural Mechanics / Ray Hulse, Jack Cain. - Palgrave Macmillan. 2000. - 592 p.

10. Faddeev D.K. Vichyslytel'nie metody lyneynoy alhebry / D.K. Faddeev, V.N. Faddeeva. M.: Hosudarstvennoe yzdatel'stvo fyzykomatematycheskoy lyteratury, 1960. - 656 s.

11. Shkurupiy O.A. Stiykist' formy rivnovahy ta dynamika dyskretnykh system: navchal'nyy posibnyk / O.A. Shkurupiy. - Poltava: PoltNTU, 2015. - 228 s. 